\title{
The First Serbian Dermatovenereologist - Jevrem Žujović
}

\author{
Bosiljka M. LALEVIĆ-VASIĆ \\ Clinic of Dermatology and Venereology, Clinical Center of Serbia, Belgrade, Serbia \\ ${ }^{*}$ Correspondence: Bosiljka Lalević-Vasić, E-mail: labuba@gmail.com
}

UDC 61:929 Žujović J.

UDC 616.5(497.11)(091)

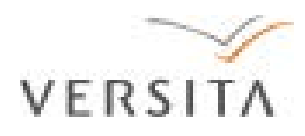

\begin{abstract}
In the early 19th century, after several centuries of slavery, Serbia was liberated and along with the overall organization of the country, health services were formed. The first specialists appeared at the end of the century, among them our first dermatovenereologist, Dr. Jevrem Žujović. He was born in 1860 in Belgrade. He attended high school in Belgrade and in 1885 he graduated from School of Medicine in Paris. Dr. Žujović specialized in dermatovenereology in Paris, with Prof. Fournier as his mentor. He was the first Head of the Department of Skin Diseases and Syphilis at the General Public Hospital since 1889. He organized specialized services all over Serbia. His activity in the work of the Serbian Medical Society was very appreciated. Dr. Žujović studied endemic syphilis and leprosy, and translated A. Fournier's book "Syphilis and Marriage", and Loraine's "Prostitution and Degeneration". Together with M. Jovanović-Batut, he wrote "Instructions on Syphilis".

As an Army Medical Officer, Dr. Žujović participated in the Serbo-Bulgarian war (1885), the First and the Second Balkan War and in the First World War (1912 - 1918). He was the vice-president of the Society of the Red Cross of the Kingdom of Yugoslavia, and the first president of the newly-founded Association of Dermatovenereologists of Yugoslavia. He was a recipient of many awards and decorations.

Jevrem Žujović retired in 1927, and passed away in 1944.
\end{abstract}

\section{Key words}

Biography; Physicians; History of Medicine; Dermatology + history; Venereology + history; Syphilis + history

$\mathrm{D}$ uring the centuries of Ottoman rule in the Balkans, the Renaissance had been flourishing in Europe, while the Serbian medieval state, its culture, nobility and most of the urban population were being destroyed (1). After a long and difficult period and national uprisings, the $19^{\text {th }}$ century was a creative period when Serbia was restored as a vasal state and definitely iberated, becoming the forerunner of the modern state. The country was facing great challenges, and organization of health services was among the most important tasks, but its basic guidelines were already present in the Constitutions of 1835 and 1838 (2). The main argument for this was the spread of infectious diseases, syphilis being one of the most significant. There were no physicians in Serbia of that time. The first physician was Dr. Alexandridi, mentioned in 1818 (2). After that, the number of physicians gradually increased, whereas specialists appeared in the late $19^{\text {th }}$ century, and one of them was Dr. Jevrem Žujović (3), our first dermatovenereologist (Figure 1). He was from a prominent Žujović family, typical in Serbia of the $19^{\text {th }}$ century; many rebels and warriors, politicians, the first educated people and intellectuals who also liberated, developed and protected Serbia, came from such families.

Fleeing from the Turks, the Žujović family moved to Serbia from Sjenica at the beginning of the $19^{\text {th }}$ century and settled in Nemenikuća under the Kosmaj Mountain. Milenko Žujović (1756- 1836), father of the family, participated in the First Serbian Uprising and died of wounds. His brother Jovan (died in 1825), a commander in the Karađorđe's 


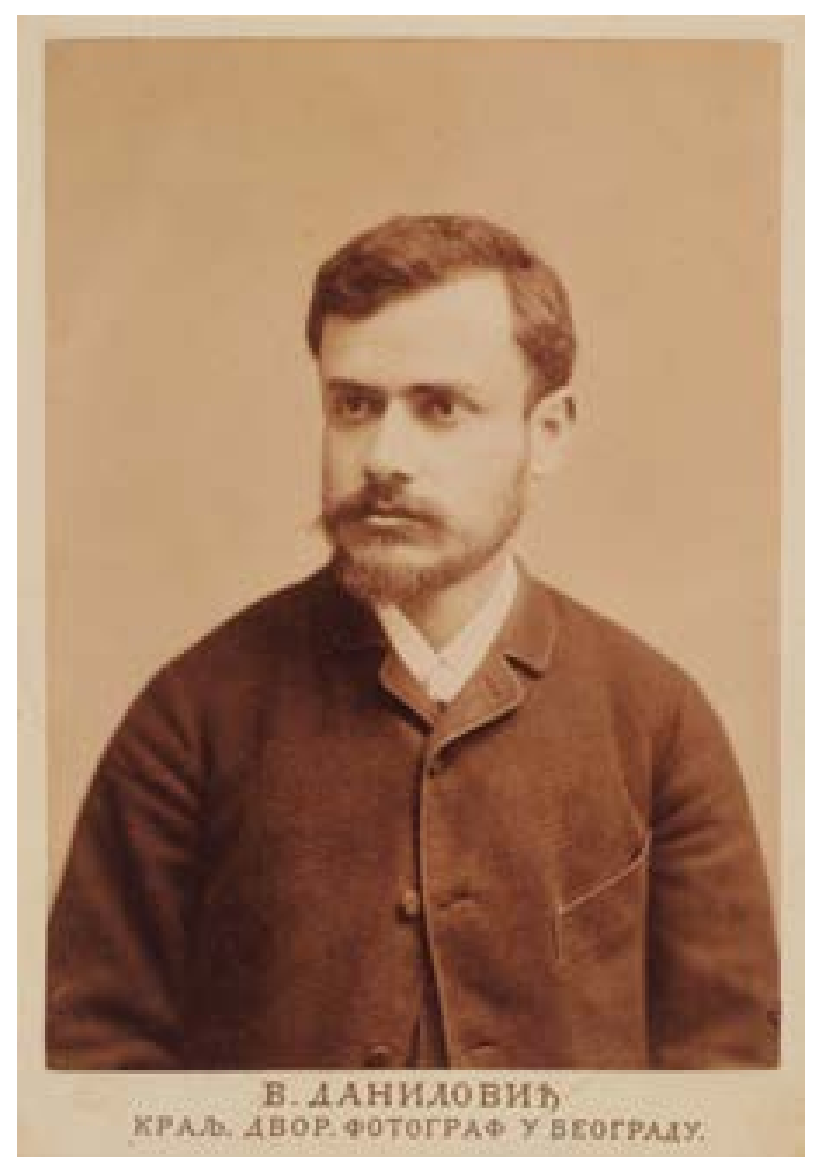

Figure 1. Dr. Jevrem Žujović, our first dermatovenereologist

(The photograph was taken by the royal photographer V. Danilović in Belgrade)

army, fought all the battles of the First Serbian Uprising (4).

Jevrem Žujovićs father, Mladen (1810-1899), was one of our first officers educated in Russia, a member of the St. Andrew Assembly, a Staff Officer of Prince Mihajlo, Mayer of the City of Belgrade, a State Advisor, Head of the Main Military Command in the rank of a Minister, and was involved in the organization of the army (4).

Jovan Žujović (1856 - 1936), Jevrem Žujović’s brother, was the founder of the Serbian geology, Professor at the University of Belgrade, Rector of the High School, a member of the Serbian Learned Society and of the Serbian Royal Academy, its president and secretary, a member of the Yugoslav Academy of Sciences and Arts in Zagreb, a member of several international scientific societies, Minister of Foreign Affairs, Minister of Education and Religions, and an important politician, especially during the First World War. He wrote a number of fundamental books and papers in his profession $(4,5)$. His name is included in the list of "The 100 most prominent Serbs" (6).

Jevrem Žujović was closely related with the Danić family. His maternal grandfather, Rista Danić (the end of the $18^{\text {th }}$ - beginning of the $19^{\text {th }}$ century), originated from Aegean Macedonia, was the president of the Belgrade municipality at the beginning of the $19^{\text {th }}$ century. His grandson, Jovan Danić, our first neuropsychiatrist and the Director of the Mental Hospital in Belgrade, was the president of the Serbian Medical Society (SMS) (4).

The descendants of Jevrem Žujović were professors at the School of Medicine and School of Law in Belgrade; one of his sons was a member of the Serbian Cultural Club, and an important politician during the Second World War (4).

Jevrem Žujović was born in Belgrade in 1860. His father was Mladen Žujović, and his mother Jelena, born Danić (see above). He graduated from High School in Belgrade in 1878 and in 1885 from School of Medicine 
in Paris, with graduate thesis "De la Thyroïdite aiguë rhumatismale" with Professor Vulpain as his mentor (4). When he returned to Belgrade, in 1885, he was appointed district physician of the Paracin District (Ćuprija County) (4). The following year (1886), he was transferred to Belgrade to a post of a secondary physician of the Mental Hospital (7). At that time, he decided to specialize in dermatovenereology, and in Europe there was a growing interest in this field of medicine. His dominant interest, however, was venereology, specifically syphilis, which was rapidly spreading. At the beginning of the 20th century, about $20 \%$ of European intelligentsia was infected with syphilis (8). Although in Serbia it first appeared at the beginning of the 19th century, after the wars for liberation from the Turks, in the thirties of the 19th century it reached epidemic proportions with numerous and often dense endemic foci (9). As mentioned before, physicians were rare, and there were no specialists whatsoever. In 1887, Jevrem Žujović went to Paris to specialize dermatovenereology in the St. Louis Hospital with Professor Fournier, a syphylologist of worldwide reputation. At that moment, medical services in Serbia already gained basic frameworks and guidelines. Some of them were of great importance for dermatovenereology, such as the Law on the Organization of the Sanitary Profession and Public Health Care, passed in 1881 (10). Based on this law, the Belgrade County and City Hospital had become the major general public hospital in the country (General Public Hospital - GPH), with five specialized departments, and Department for Skin Diseases and Syphilis among them (11). In 1882, Prostitution Regulations Rules were brought (12), as well as the Law on Sanitary Funding, in 1879, independent from political interference, putting Serbia ahead of Europe (13). The official announcement about free treatment of syphilis among laborers "workers and peasants" (1887) was also of utmost benefit (2). Jevrem Žujović returned from specialization in 1888 (4), so an educated dermatovenereologist arrived to Serbia at the right moment and his knowledge was well used. He came from one of the leading European dermatovenereological center where modern medicine was being born and where the fight against syphilis was at the highest level. Apart from that, as the rest of our intellectuals of that time, with a high national consciousness and sense of duty, energy and creativity, which had been restricted and accumulated over the centuries, he started the development of a specialized dermatovenereology service. Although a dermatovenereology department was planned by the Sanitary Law from 1881, its professional organization began when Jevrem Žujović returned from Paris. With no time to spare, in August of the same year, he sent a request to the Administration of the GPH, describing the situation he found in the venereology service in Belgrade, and we will quote part of it: "The Women's Ward for Skin Diseases and Syphilis has 1 room with 13 beds; now there are 30 infected patients, with 2 or even 3 patients per bed. One or two infected women are sent by the police every day, and apart from this, 3-6 prostitutes are referred from brothels every week. Other infected women (so called private), are not admitted, but they are treated as outpatients. None of the venereal diseases can be cured in 7 days, and patients referred by the police cannot be discharged before completely cured. Therefore, it is necessary to raise a building with $2-3$ rooms with $30-40$ beds" (14). The Superintendant of the GPH, Dr. Gonsjorovski immediately wrote a request to the Minister of Internal Affairs: "Please urge the competent authorities to build at least one soft material building in the hospital park to accommodate 40 beds for female patients", having in mind patients suffering from venereal diseases (15). The problem was eventually solved, because there were reports about barracks in the yard of the GPH, although there are no documents about their work. The following year, in 1889, as the first and only dermatovenereologist, Jevrem Žujović was elected Head of this Department (4) and organized its work as well as the work of the whole network of dermatovenereological services in Serbia. At the same time, he implemented a modern dermatovenereological doctrine at the above mentioned territory. His collaboration with the dermatovenereology services in all areas of the country was well functioning, and his department became a training center for physicians, where unsolved and critical cases were sent to from all over the country. Prof. Dr. Đ. Đorđević said the following: "Thanks to his quiet, serious and professional work, he managed to keep our profession at a high level in the most critical times for dermatovenereology.... His department was 
of such importance that all the others looked up to him, followed his work and thus implemented their knowledge in practice, particularly in relation to syphilis"(16). All the time he kept close ties with European dermatology and in 1909 he revisited the St. Louis Hospital, spending 3 months getting familiar with novelties in the profession. Upon his return, he established a modern laboratory at his department and for the first time in Serbia introduced Wasserman reaction and microscopic detection of Treponema pallidum from syphilis lesions $(4,17)$.

Although the bibliography of Jevrem Žujović is not complete, reviewing Serbian Archives for the Whole Medicine, one can find that he was very active in the SMS, where he reported about rare skin diseases, new therapeutic procedures, translated recent articles and outlines from foreign literature, and presented congress reports from international congresses he attended. As the Prof. Fournier's student, he paid special attention to endemic syphilis. He also studied leprosy, and from 1890 till the Balkan Wars (1912 - 1913), during his holidays, he travelled through Eastern Serbia, Bosnia, Herzegovina and Montenegro, collecting materials about leprosy and syphilis. Unfortunately, documents that he did not get to finish, including medical histories and diary reports, were mostly destroyed during the occupation of Serbia (1914 - 1918) (4). A typewritten text signed by Dr. Jevrem Žujović was saved and it analyzed the incidence of leprosy in Serbia according to annual reports of all hospitals in the country since 1888 , and based on papers presented on all meetings of the SMS since its establishment (1872) (18), and reports of several colleagues who worked in areas with leprosy. Zambaco Pasha, a famous Greek leprologist from Istanbul and a naturalized Frenchman, published the material in his book before 1914 in French (19). Another typewritten and signed paper by Dr. Žujović was also saved: "Rapport de la Société de la Croix rouge des Serbes, Croates et Slovènes à la Conference régionale de l'Europe orientale sur les maladies veneriennes "and he presented it in Prague in 1921. This paper has 11 pages and presents a precise and detailed description, always characteristic for his writing, of the development and organization of the fight against syphilis in the whole country. Although everything he wrote about was legally documented, as a member of the Sanitary Council he clearly expressed his own opinion about the dermatovenereology service, and summerized his lifelong experience into a series of principles which even today seem incredibly true (20).

Apart from this, in 1892 he translated the book of his mentor, A. Fournier: "Syphilis and Marriage", which was the first book on venereology in Serbian language. He also translated the book "Prostitution and Degeneration" by Loraine, which was published in series in Serbian Archives for the Whole Medicine. According to the decision of the SMS, together with M. Jovanović-Batut, he wrote "Instructions on Syphilis" (vrenga) (21).

In 1887, Jevrem Žujović was elected a member of the SMS. Shortly thereafter, in 1888, he became a deputy, and then a regular member of the Sanitary Council of the Ministry of Internal Affairs and remained at this important function in the course of thirty years $(4,7)$. Being our most eminent dermatovenereologist of that time, in 1927 he was elected the first president of the Association of Dermatovenereologists of Yugoslavia (16).

In addition to his work in his profession, as a member of the Sanitary Council he was engaged in the organization of health services in Serbia. He paid great attention to health education of individuals, the society and especially of the rural population. In one of his papers he wrote about this problem, which points to his personal participation in health education (20). Apart from the fact that he set his profession into the framework of newly adopted sanitary regulations and opened the route for entering and accepting European scientific dermatovenereology, Jevrem Žujović was very active in wars his country was engaged in. At the very beginning of his medical career, as a regimental doctor, he took part in the Serbo-Bulgarian war that erupted at the end of $1885(4,17)$.

He participated in both Balkan Wars and in the First World War (1912 - 1918) as a Reserve Medical Officer. From October 1912 to August 1913, he was the commander of the Third Field Hospital of the Sumadija Devision, located behind the battle lines, and then organized a Reserve Military Hospital in Prizren, which had to be transformed into a hospital for patients with typhoid fever. At the end of Balkan Wars, he founded a hospital in Stracin for patients suffering from cholera. During the First World War, in 1914, 
he served in the Belgrade Military Hospital as a Reserve Sanitary Major. Soon he was transferred to Đevđelija for the commander of the Reserve Military Hospital, when he himself got spotted typhus which decimated the Serbian army and the Serbian medical staff, and in mid-1915 he moved to Skoplje and became the Head of the Military Hospital and Chief of the Department for Skin and Venereal Diseases. After that, as a member of the Red Cross Committee, he joined the Serbian army in retreat, and via Peć and Skadar he arrived to St. Jovan Medovski on the Adriatic coast. During this painful exodus, Jevrem Žujović and a prominent retailer from Belgrade Đ. Radojlović, also a member of the Red Cross Committee, helped temporary hospitals on their way, and then used the Red Cross funds to organize kitchens and hospitals in Skadar and Lješ for the exhausted and wounded soldiers. At the end of January 1916, they both went to Geneva and with the help of the International Red Cross Committee and by virtue of their own authority and diligence, they organized the Red Cross Information Bureau, which provided financial assistance to prisoners of war and the population in the occupied Serbia. In recognition of his outstanding work, in 1920, the League of Red Cross Societies elected J. Žujović a member of the Board of Governors of the League. He was the first vicepresident of the Society of the Red Cross of the Kingdom of Yugoslavia (4).

For his peacetime and wartime merits, J. Žujović received the following awards: Order of White Eagle, IV class, Memorial Medals for 1885 and 1886, Gold Medals for diligent service, and three Orders of St. Sava (II, IV and V class), as well as the Belgian Red Cross Decoration I class (4).

After the war, J. Žujović continued working at the Department for Skin Diseases and Syphilis of the GPH in Belgrade. His department has always been recognized for its innovative ways and commitment to research and it cooperated with renovated and new dermatovenereology institutions in Belgrade and Serbia, while his experience, reputation and authority were the backbone of rapid postwar development of our profession. His help in practical teaching of dermatovenereology at the newly established School of Medicine in Belgrade should also be pointed out (22).

J. Žujović retired in 1927 . He passed away on the Orthodox New Year, January 14, 1944, at his home in 42 King Milan Street, and was buried at the New Cemetary in Belgrade (4). He did not live to see the liberation of his country, for which he had done so much.

\section{Abbreviations}

SMS - Serbian Medical Society

GPH - General Public Hospital

\section{References}

1. Marković P. Najgori trenuci srpske istorije [The worst moments of Serbian history]. Politika [kulturni dodatak]. 2011; Sept 10:3.

2. Mihailović V. Istorija polnih bolesti u Srbiji do 1912. godine [The history of venereal diseases in Serbia up to 1912]. Beograd: Štamparija centralnog higijenskog zavoda; 1931.

3. Ignjatović M. Laza K. Lazarević (1851-1891): II deo. Vojnosanit Pregl 2002;59(1):87-93.

4. Žujović Dj. Uspomene iz detinjstva [Childhood memories]. Beograd: J. i G. Žujović; 1997.

5. Košanin N. Žujović Jovan. In: Stanojević St, editor. Narodna enciklopedija srpsko-hrvatsko-slovenačka. Knj. 1. [National Encyclopedia - Serbo-Croat-Slovene. Volume I]. Zagreb: Bibliografski zavod DD; 1928. str. 752-3.

6. Grupa autora [Group of authors]. 100 najznamenitijih Srba (po SANU) [The 100 most prominent Serbs (by the SASA]. Beograd, Novi Sad: Princip; 1993.

7. Kalendar sa šematizmom za godine 1886-1889 [Schematized Calendar for 1886 - 1889]. Beograd: Državna štamparija; 1890. 8. Thaller L. Značenje povijesne medicine [The role of the history of medicine]. Med Pregl (Bgd) 1927;2(7-8):274-6. Citirano u [Quotes from]: Ignjatović M. Izučavanje istorije vojne medicine $i$ hirurgije [The study of the history of military medicine and surgery]. Vojnosanit Pregl 2002;59(4):429-35.

9. Ilić S, Ignjatović B. Endemski sifilis u Srbiji [Endemic syphilis in Serbia]. Beograd: Biblioteka higijenskog instituta NR Srbije; 1957.

10. Zakon o uređenju sanitetske struke i o čuvanju narodnoga zdravlja. [Law on the organization of the sanitary profession and public health care]. Srp Nar Nov 1881 Apr 4;49(75).

11. Zakon o uređenju sanitetske struke i o čuvanju narodnoga zdravlja [Law on the organization of the sanitary profession and public health care]. Srp Nar Nov 1881 Apr 10;49(80):čl.26.

12. Garašanin M. Pravila o regulisanju prostitucije [Prostitution regulation rules]. Nar Zdrav 1882;1:10-3.

13. Đorđević V. Laboremus! Pozdrav I kongresu srpskih lekara i prirodnjaka (prvih 100 godina u razvitku lekarske struke u Srbiji) [Greetings to the First Congress of Serbian physicians and naturalists (the first 100 years of the development of the medical profession in Serbia]. In: Subotić VM, Kujunđić V, editors. Zbornik radova I kongresa srpskih lekara i prirodnjaka (održan 1904). Knjiga 1 [Proceedings of the First Congress of Serbian physicians and naturalists (held in 1904). Volume I]. Beograd: Univerzitet; 1905. p. 44-69.

14. Akt R.421/88. Beograd 31. avg. 1888. Arhiv Srbije.

15. Akt no 833. Beograd 22 sept. 1888. Arhiv Srbije. 
16. Skupština jugoslovenskih dermatologa i venerologa za osnivanje Jugoslovenskog dermatovenerološkog društva [The Assembly of Yugoslav Dermatologists and Venereologists for the constitution of the Association of Dermatovenereologists of Yugoslavia]. Srp Arh Celok Lek 1927;29(5):421-6.

17. Žujović J. Biografija. Beograd: Arhiv Muzeja Srpskog lekarskog društva [kucani tekst sa potpisom autora: nezaveden] [Biography: Archives of the Museum of the Serbian Medicine of the Serbian Medical Society (a typewritten document signed by the author - unrecorded)]. (sine ano).

18. Đorđević SP. Obrazovanje Srpskog lekarskog društva u Beogradu i osnivanje njegovog časopisa "Srpski arhiv za celokupno lekarstvo" 1872. godine [Constitution of the Serbian Medical Society in Belgrade and Foundation of its journal Serbian Archives for the Whole Medicine]. Srp Arh Celok Lek 2005;133(1-2):91-100.

19. Žujović J. Statistique de la lèpre en Serbie et les mesures prises contre sa propagation. Beograd: Muzej srpske medicine Srpskog lekarskog društva (kucani tekst sa potpisom autora - nezaveden) [Museum of the Serbian Medicine of the Serbian Medical Society (a typewritten document signed by the author - unrecorded)]; 1913.

20. Žujović J. Rapport de la Société de la Croix rouge des Serbes, Croates et Slovènes à la Conférence régionale de l'Europe orientale sur les maladies veneriennes. Beograd: Muzej srpske medicine Srpskog lekarskog društva (kucani tekst sa potpisom autora: nezaveden) [Museum of the Serbian Medicine of the Serbian Medical Society (a typewritten document signed by the author - unrecorded)]; 1921.

21. Jeremić R. Bibliografija srpske zdravstvene književnosti [Bibliography of Serbian Medical Literature]. Beograd: Biblioteka Srpskog lekarskog društva. [Library of the Serbian Medical Society]; 1947.

22. Kićevac M. Klinika za kožne i venerične bolesti [Clinic for Skin and Venereal Diseases]. In: Medicinski fakultet Univerziteta u Beogradu 1920-1935. Beograd: Medicinski fakultet; 1935. p. 125-31.

\section{Prvi srpski dermatovenerolog - Jevrem Žujović}

\section{Sažetak}

Uvod: Devetnaesti vek je stvaralački period srpske istorije, kada je posle viševekovnog ropstva pod Turcima nastala „obnovljena“, a potom i slobodna Srbija. Uporedo sa celokupnom organizacijom zemlje počelo je i formiranje zdravstvene službe; pojavili su se prvi lekari, ali se specijalisti sreću tek krajem XIX veka, među kojima je bio i naš prvi dermatovenerolog - dr Jevrem Žujović. On je poticao iz ugledne porodice Žujović, koja je davala ratnike, političare i naučnike. Biografski podaci: Jevrem Žujović se rodio u Beogradu 1860. godine. Gimnaziju je završio u Beogradu 1878. godine, a Medicinski fakultet u Parizu; 1885. lekarsku službu je počeo 1885. kao okružni lekar, ali već 1887 . otišao je u Pariz da specijalizira dermatovenerologiju. Stručna aktivnost: Specijalizaciju je obavio kod prof. Furnijea (Fournier), vodećeg evropskog sifilologa. U zemlju se vraća 1888. godine, a za šefa Odeljenja za kožne bolesti i sifilis izabran je 1889 . U to vreme sanitetska služba u Srbiji već je dobila zakonske okvire i smernice, tako da su kapaciteti J. Žujovića mogli biti iskorišćeni. On organizuje specijalističku službu na svome odeljenju, učestvuje u stvaranju mreže specijalističke službe u celoj Srbiji i sprovodi savremenu dermatovenerološku doktrinu na celom području. Đ. Đorđević kaže da je njegovo odeljenje bilo od takve apsolutne vrednosti, da su se svi po njemu upravljali. Posle ponovnog boravka u pariskoj bolnici, 1909. godine, osniva modernu laboratoriju i u rad uvodi Vasermanovu reakciju i mikroskopsko otkrivanje blede treponeme sa kožnih lezija.

Bio je vrlo aktivan u radu Srpskog lekarskog društva, gde je prikazivao retke dermatoze, nove terapijske postupke, prevode aktuelnih članaka iz strane literature i izveštaje sa inostranih kongresa u inostranstvu. Proučavao je endemski sifilis, a njegov izveštaj o pojavi lepre u Srbiji štampan je u knjizi koju je objavio poznati leprolog toga doba, Zambaco Pasha. $\mathrm{Na}$ Regionalnoj konferenciji istočne Evrope o veneričnim bolestima, 1921. godine izneo je iscrpan izveštaj u ime Crvenog krsta Kraljevine Srba, Hrvata i Slovenaca. Preveo je dve knjige sa francuskog jezika: „Siflis $i$ brak", A. Furnijea i "Prostitucija i degenerisanje“ Lorana (Loraine), a zajedno s M. Jovanovićem - Batutom izradio je „Pouke o sifilisu“. Pružao je pomoć u praktičnoj nastavi iz dermatovenerologije na novoosnovanom Medicinskom fakultetu u Beogradu. Učešće u ratovima: Učestvovao je u Srpsko-bugarskom ratu (1885), u oba Balkanska rata i u Prvom svetskom ratu (1912-1918) kao rezervni sanitetski oficir. Prateći srpsku vojsku preko Albanije organizovao je kuhinje, poljske i rezervne vojne bolnice, pri čemu je i sam oboleo od pegavog tifusa. Iz Ženeve, uz 
pomoć Međunarodnog komiteta Crvenog krsta, zajedno sa Đ. Radojlovićem organizovao je pomoć ratnim zarobljenicima i stanovništvu u okupiranoj Srbiji.

Druge aktivnosti: Bio je potpredsenik Drustva Crvenog krsta Kraljevine Jugoslavije i član Saveta guvernera Lige drustava Crvenog krsta. Kao vodeći dermatovenerolog 1927. godine izabran je za prvog predsednika novoosnovanog
Jugoslovenskog dermatovenerološkog društva. Nosilac je sledećih odlikovanja: Orden belog orla IV stepena, ratne spomenice 1885. i 1886. godine, Zlatne medalje za revnosnu službu, tri Ordena Sv. Save (II, IV i V reda) i Medalje I klase Belgijskog crvenog krsta. J. Žujović se povlači u penziju 1927. godine. Preminuo je 1944. godine.

\section{Ključne reči}

Biografija; Lekari; Istorija medicine; Dermatologija + istorija; Venerologija + istorija; Sifilis + istorija 